Article

\title{
The Impact of Innovation on the Firm Performance and Corporate Social Responsibility of Vietnamese Manufacturing Firms
}

\author{
Nguyen Thi Canh ${ }^{1}$, Nguyen Thanh Liem ${ }^{1, * \mathbb{D}}$, Phung Anh Thu ${ }^{2, * \mathbb{D}}$ and \\ Nguyen Vinh Khuong ${ }^{3}$ (]) \\ 1 Center for Economic and Financial Research, University of Economics and Law, VNU-HCM, \\ Ho Chi Minh City 700000, Vietnam \\ 2 Faculty of Finance and Accounting, Nguyen Tat Thanh University, Ho Chi Minh City 700000, Vietnam \\ 3 Faculty of Accounting and Auditing, University of Economics and Law, VNU-HCM, \\ Ho Chi Minh City 700000, Vietnam \\ * Correspondence: liemnt@uel.edu.vn (N.T.L.); pathu@ntt.edu.vn (P.A.T.); \\ Tel.: +84-283724-4555 (N.T.L.); +84-7725-25700 (P.A.T.)
}

Received: 6 June 2019; Accepted: 28 June 2019; Published: 4 July 2019

\begin{abstract}
Innovation is a complex process and has been shown to be influential towards different types of stakeholders. From the viewpoint of stakeholder theory, shareholders and creditors are more likely to be concerned about corporate financial performance. However, in the new era an enterprise's responsibilities have to extend to other stakeholders, including its employees, suppliers and communities. This study aims to extend the literature by examining the individual effects of product and process innovations, and then their interactions with external collaboration, on firm performance and corporate social responsibility (CSR) activities in terms of local contributions for a sample of Vietnamese manufacturing firms during 2011-2013. Research findings suggest that process and product innovations are beneficial to firm performance in terms of market share, but not return on total assets. This implies that investment in innovative activities requires time to make positive changes in profitability, but it may help with winning customer loyalty. We also find evidence suggesting that innovation could make firms more obscure, especially when there are external parties involved. This motivates firms to send signals about their sustainability and goodwill through corporate social responsibility (CSR) activities. With regard to CSR activities, we are the first to provide a breakdown of categories of corporate social contribution towards the local well-being, and elaborate evidence on the effect of innovation on each category, rather than just a composite index of CSR as in some extant studies.
\end{abstract}

Keywords: process innovation; product innovation; openness; firm performance; corporate social responsibility; manufacturing industry

\section{Introduction}

Increased global and regional competitions have led firms to determine to create or sustain competitive edge by engaging in innovation. A fast-changing environment with constant abrupt changes makes it indispensable for firms to build up their capability to innovate [1]. Innovativeness is not only a matter of interest to practitioners, but has drawn great academic attention, especially in investigating the effect of several innovation specifications on firm performance. Among the innovation specifications, product and process innovations are often examined. With the rapid technological change in recent decades, modified products (product innovation) or alterations in the ways that they are produced (process innovation) are often witnessed in the manufacturing industry $[2,3]$. 
Even though innovation tends to be associated with improvements in economic performance [4,5], researchers remain uneasy in generalizing this positive impact of process and product innovations on firm performance. Some studies suggest that process innovation is more efficient and able to support firms better, while others provide evidence in support of the reverse arguments.

Innovation is rather involved and sometimes requires collaboration with outside stakeholders (open innovation), and this act encourages knowledge sharing, risk abatement, and development speed [6,7]. With an increased rate of evolution in consumer tastes and technology, open innovation proves to be indispensable [8]. These substantial merits urge researchers to empirically examine whether open innovation is positively influential towards innovation outcomes. Much as literature has incorporated several dimensions of open innovation (e.g., breadth, depth), little has been done in examining the impact of the interaction between external collaboration and process and product innovation on firm performance, at least in a developing country setting. A study of the effect of open innovation for manufacturing firms in developing countries is warranted since, compared to counterparts in more developed markets, innovation in firms in developing countries tends to be more determined by foreign direct investment (FDI) and external technology transfer, rather than by built-in capacity or domestic R\&D expenditure [9].

In many studies, the outcomes of innovations are often measured in terms of innovative outputs, such as the number of development projects, increase in sales from new products, or the frequency of new product launches $[10,11]$. This focus is intuitive since it relates directly to the innovation outcomes. However, it could also be of considerable interest to evaluate the impact of innovation types on general performance, e.g., total sales, profits, or market share for all products/services. After all, innovation is in place not only to bring improvements to just one or two products, but can affect firms' range of products/services. The overall economic performance should be a better indicator of a firm's sustainable development compared to just the innovative performance of a firm. The present study will seek answers to the question of how process and product innovations affect firms' overall performance, rather than innovative outputs, to fill this gap.

Another issue that emerges in the new era is that firms cannot just focus on economic performance and ignore social and environmental concerns [12]. Furthermore, according to Pizzi [13], if a firm lacks control over the environmental impact of its activity, consequential negative implications on the financial performance may occur. However, the integration of these areas is not straightforward and firms need to find strategies for this [14]. This new requirement comes from a shift in the emphasis of the lead stakeholder in sustainable development: initially, the role of governments was highly visible, while in the 1990s, civil society actors gain currency, and from the beginning of the new millennium, businesses have more of a role to play [15]. With this development, as well as increasing demand from consumers and governments, firms should be inclined to be socially responsible and show commitment to contribute to the local community and society at large, and it is increasingly unacceptable to engage in unethical business practices, including child labor, environmental pollution.

In this context, on the one hand, a firm's corporate social responsibility (CSR) is a strategy to respond to the new social requirements. CSR is expensive, but firms could voluntarily invest in this field to compensate for any adverse impacts of their operations towards the environment and societal well-being. It is shown that firms could enhance the prospect of leveraging reputational gains to earn profits from CSR activities, at least in the medium run [16]. In addition to this, CSR could address information asymmetry arising from firm innovation and stakeholders, but this link is scantily researched. Ramani \& Mukherjee [17] suggest that the relationship between radical innovation and other corporate strategies, especially CSR, have not been underresearched. In the context of innovation, CSR-related researches mainly delve on environmental sustainability [17], while studies on other facets of CSR, such as the contribution to local sustainable development, are silent [18].

The innovations could be more interesting to the shareholders and debtholders, but how would innovative firms choose to interact with other stakeholders such as the local community, i.e., its tendency to contribute to the local well-being? The local sustainable development could be secured by improving 
environmental conditions, uplifting education, sport, and health standards, alleviating poverty, preserving heritage, etc. Since technological advancement and innovation have impacted both economy and society as a whole [19], the study of their impact on societal development should not be neglected. Nonetheless, the link between product and process innovations and local sustainable development as a form of corporate CSR has been largely unexplored.

We posit that the overall performance should be analyzed in addition to innovative performance, which has already been heavily discussed in prior literature. The performance indicators to be examined in this paper will not only cover economic but also social contribution, to make sure that a more well-rounded view of the impact of innovation is under investigation. Another contribution of the present paper is the study of the influence of product and process innovations in a vacuum, and of whether external collaboration in the making of these two innovations is more beneficial than a closed process. A firm's resources for open innovation activities are particularly limited in developing markets, as these activities are costly yet unable to bring certain positive outcomes [9]. This is why an attempt to investigate the role of collaboration in product and process innovations is essential, both in academic and practical meanings. The final contribution is that we study innovations in Vietnam, a developing country that has gained relatively robust growth thanks to a strong focus on technological change for sustainable development. Even though Vietnam in specific, and other developing countries in general, rely heavily on innovation, very few studies on innovation have been conducted for these economies. We provide a concrete breakdown of different types of firms' CSR strategies, rather than just a composite index of CSR to shed some light on which type of CSRs local contribution firms may prioritize.

\section{Literature Review}

\subsection{Product and Process Innovations and Impact on Firm Performance}

The Organisation for Economic Co-operation and Development (OECD) Manual [20] has categorized four types of innovation: product, process, marketing, and organizational innovations. The outcome of product innovation is the introduction of a both marginally or radically improved good or service with respect to functions, characteristics, or components. Product innovation is mostly induced by demand factor, but supply side could be a significant driver for this type of innovation as well [21]. Upgraded technologies, changing customer tastes, and shortening product life cycles, combined with overall increased global and regional competition, force firms to innovate relentlessly [22]. Process innovation leads to improvements in the methods of production or delivery of products/services [20]. The process could be new, or significantly improved compared to the existing version. The theory of creative destruction by [23] proposes that innovative firms have the competitive edge that enables them to replace noninnovative ones. Innovation has been identified as a sustainable channel to facilitate economic growth and corporate performance. Theoretically, innovation is expected to facilitate enhancements in firm economic performance. Nonetheless, empirical results have not always been in line with this expectation, i.e., there are a number of studies that suggest that innovations do not necessarily bring better performance.

Some studies find a more preferable effect of process innovation over its product counterpart. Hall et al. [24] found that firm size, investment in R\&D are drivers of product and process innovations for Italian small and medium enterprises (SMEs). The researchers documented the positive influence of both product and process innovations on SMEs' productivity, but the latter proves to be more eminent. Hall et al. [24] also found that the link between innovation and productivity is weaker for larger and older firms. Waheed [25] performed a similar examination using a sample of firms in Bangladesh and Pakistan, and confirmed that process innovation influences productivity more than product counterpart. Tuan et al. [26] found that product innovation appears to have an insignificant impact on innovative performance, whereas the other three types (process, organization, and marketing innovation) have more marked influence on innovative outcome for firms in supporting industry. 
Hall [4] reviewed the empirical evidence on the link between innovation and productivity. The author found substantive evidence on the positive effect of product innovation on revenue, but process innovation shows a more hazy effect. Rosli and Sidek [27] examined a sample of roughly 300 firms in the industry of a wide range of sectors in Malaysia. They found that both product and process innovation positively relate to firm performance, where the impact of the former is stronger. Tuan [28] used a sample of 353 manufacturing SMEs in Vietnam, and found that gender, product innovation and firm reputation positively impact the growth of manufacturing SMEs.

On the other hand, product innovation is found to be superior to process one in some studies. Fagerberg [29] contends that new product introduction could exert a strong and positive impact on the growth of income and employment, meanwhile process innovation shows a more controversial effect probably due to this innovation type being more prone to cutting costs. Foster et al. [30] suggest that firm-specific demand variations, rather than technical efficiency, are the dominant factor in determining firm survival and positively influence measured productivity. Product innovation should relate more to firm-specific demand variations, whereas process innovation is expected to affect technical efficiency. Using a sample of French firms in manufacturing and service industries, Mairesse and Robin [31] show that product innovation tends to be the dominating driver of labor productivity, while process innovation is both economically and statistically insignificant. Studying a sample of firms in four European countries, Griffith et al. [21] argue that firms are more likely to engage in formal innovative activities, and that product innovation are demand-driven, while process is supply-driven. These authors also posit that process innovation only helps increase productivity in France, while product innovation is more effective and raises productivity in France, Spain, and the UK. Cassiman et al. [32] found strong evidence that product innovation, not process innovation, affects productivity.

In summary, the prior literature in this session tends to suggest that, in developing countries, e.g., Bangladesh, Pakistan, and Vietnam, process innovation is a stronger driver for firm performance, while in developed countries (e.g., European countries), the opposite is often found. One more noteworthy point is that the performance indicator in those studies mainly discuss innovative performance, i.e., how do products from innovation activities sell. However, this leaves the questions of how overall performance, i.e., how the firms' well-being fares, e.g., the sales in general and market share of firms, unanswered. From the literature reviewed, though there are cases of negative influence of these two types of innovation, the general theme is still leaning towards their positive impact on firm performance [33-35]. Our first hypothesis is, therefore, as follows:

H1. Innovation is positively correlated with firm economic performance.

\subsection{Open Innovation, Levels of Newness, and Firm Performance}

Open innovation relates to the way firms interact with external stakeholders to innovate, as innovation itself is not straightforward and rather involved. The term open innovation refers to the collaboration with external stakeholders, while closed innovation incurs when internal R\&D expenditures and in-house research team help with all the organizational innovations [8]. The majority of studies on open innovation strategies demonstrate a positive influence on innovative performance [35]. This is clear evidence in support of the preferential effect hypothesis, because it is expected that firms that interact with outsiders have higher chances of internalizing external ideas and technologies. This would altogether create conditions for firms to innovate successfully.

Despite the expected merits from open innovation, studies have cast doubt on whether openness invariably leads to higher firm performance. This is because firms' resources are naturally limited, while collaborating with external partners is costly and demands high maintenance costs [36-38]. Lin [39] pinpoints that, in a cost and benefit framework, the marginal return from open innovation may be diminishing and excessive reliance can turn out to negatively influence firm performance. Duyster [36] and Kang and Kang [39] have documented an inverted U-shaped relationship between open innovation and innovative performance. In other words, oversearch and overcooperation 
might erode the marginal returns from open innovation when a firm continues its reliance on additional externality.

Laursen and Salter [11] analyzed open innovation under breadth and depth perspectives. These authors hypothesize that broader and deeper deployment of external collaboration could enable firms to innovate more efficiently. Breadth relates to the number of external sources of information, while depth defines the degree of information that firms can draw from external sources of information. Bayona-Saez et al. [40] also examined the effect of openness on firm innovative performance. The study results suggest that incremental innovations chiefly depend on firms' internal capability, and not on firms' openness. However, one dimension of openness, breadth, does affect radical innovations. Diverting from other studies on the separate effect of coupled and inbound openness, Greco et al. [36] also contributed by investigating the synergistic impact of inbound openness on innovation performance.

Firms need external partners in R\&D activities to develop and maintain competitiveness and the utmost economic success. Open innovation is expected to help firms transcend beyond traditional operating models and lift up firm boundaries. Gobbo and Olsson [41] argue that innovation includes both the search for knowledge novelty and the application of available knowledge, which is essential to materialize firms' potentials. Inauen and Schenker-Wicki [42] suggest that companies focusing on open innovation are more likely to perform radical innovations, and are able to sell a higher quantity of new products.

Radical innovations are inherently more uncertain and complex, thus requiring difficult skills compared to incremental innovation [43]. Radical innovation enables firms to enhance value, rarity, and inimitability, helping firms to maintain the foundation for a competitive edge. Rubera and Kirca [44] found that radical innovations are more of an enabler for positive performance, compared to incremental innovations. The role of newness of innovation could be particularly helpful in an environment where minor innovations could easily imitate other firms' innovative efforts. In a developing context, resources for R\&D research, such as financing and human capital, are considerably limited. External sources such as FDI and through external collaboration are important, and aid much in firms' innovation [9]. Therefore, openness in innovation is critical and is expected to bring desirable outcomes, and help firms to improve in general. According to the preferential effect hypothesis, it is expected that firms that interact with outsiders have higher chances of internalizing external ideas, technologies, and creating edges. Openness helps bring together resources, knowledge, and risk-sharing function [6], thus supporting the likelihood of a firm to engage in innovative activities as well as the success of such deeds. Given the critical role of open innovation and the link between open innovation and the likely resultant economic success found in the literature, our second hypothesis is as follows:

H2. In a developing country, product and process innovations are more efficient when conducted with external support.

\subsection{Innovation and Corporate Social Responsibility}

Strategic management studies have emphasized the important role of corporate social responsibility in creating a long-term competitive advantage [45]. CSR is a strategy depending on how a firm selectively identifies and attends to its main stakeholders' interest [46]. Since CSR has a broad impact on other strategies and performance, it is critical to examine the determinants or rationales for why a firm engages in CSR [18]. Extant literature suggests that CSR is employed to boost corporate reputation, satisfy stakeholders, and improve social image [47,48]. CSR is also a tool to differentiate a firm from other firms. Most studies emphasize that when CSR is included in a corporate strategy, it tends to enhance technological innovation investment $[49,50]$. However, the reverse direction of how innovation imposes on a firm's decision to take part in CSR is hardly examined [51].

Firms reap vast benefits from innovation, but this strategy can also be problematic towards firm performance [52]. Innovation is risky and requires lots of firm-specific investments, because of its intensive needs for capital, but the returns from investment in innovation are purely unpredictable [53]. 
In fact, stakeholders may voice their concern about a firm's innovation activities since these are transaction-specific investments. Each innovation investment probably requires a unique set of human capital, equipment and facilities, and skills or technology; as a result, it would be too costly to end a contract to start an innovative project [18]. This is particularly true if the focal firm is not sustainable. What exacerbates the information asymmetry problem is that innovative activities are overly complex, and investors barely have decent control over the innovation. Hart and Moore [54] suggest that, if a firm is unstable, investment is likely to be wasted in the long term, and stakeholders would be hesitant to cooperate with the firm.

Signaling theory suggests that firms could signal their sustainability as well as goodwill. Spence [55] and Stiglitz [56] contend that, for signals to be effective, two criteria must be satisfied, which are observability and sufficient costliness. CSR is a strategy that can fulfill these two criteria of an effective signaling channel. First, CSR is highly observable, and can raise the awareness from all kinds of stakeholders [57]. The second criterion emanates from the convention that exorbitant expenditure spent can only be paid by sustainable firms. [18,58] found that evidence supporting CSR can serve as a decent signaling channel. Using a sample comprising 3315 US listed firms from 2001 to 2011, Shen et al. [18] results indicate that highly innovative firms contribute more via CSR.

Signaling theory regards CSR as a channel to convey a firm's sustainability to outsiders in an effort to receive continuous support from them. In a developing country, the signaling motivation should be stronger due to higher potential malicious effect of information asymmetry [59]. In addition, innovation is highly risky; as a result, signaling drive should be significant in the case of innovative firms. The obscurity of both process and product innovations may leverage significantly when there is a collaboration. This is because open innovation is usually sought when firms are to perform more radical innovations, and closed innovation has a tendency to lead to more incremental enhancements. As Leifer et al. [43] emphasize that radical innovation has more uncertain outcomes, we could infer that firms conducting open innovations would expose themselves to more scrutiny from outsiders, which further requires firms to provide signals about their sustainability. Accordingly, with regard to the signaling theory our two final hypotheses are:

H3. Both process and product innovations are more likely to be associated with social contribution if conducted with external stakeholders.

\section{Research Methodology}

\subsection{Estimation Method and Research Sample}

The data of this study are comprised of manufacturing firms in Vietnam during the period of 2011-2013. The General Statistic Office of Vietnam (GSO) conducted Vietnam Technology and Competitiveness Surveys spanning the 3-year period, collecting information about the employment of technology and corporate social responsibility in the manufacturing industry. This is a large-scale survey effort covering thousands of manufacturing firms in Vietnam. These surveys covered part of a larger sample of manufacturing firms (8386 firms) in Vietnam Enterprise Surveys, which is conducted also by the General Statistic Office, covering more than 50,000 manufacturing firms.

To obtain economic performance indicators as well as other firm characteristics, we merge this dataset with the Economic Survey, also conducted by GSO during the same period using the instrument provided by GSO staff. The instrument was created by concatenating provincial code and entity code. Both of these datasets were administered by mailing out the survey forms to firms, and the firms return the completed forms by post. One factor that facilitates the collection of the dataset is that it is mandatory for firms to complete the form, under the law on Statistics, otherwise they will be contacted by the authority.

Conventionally, fixed-effects and random-effects methods are used for estimating models with panel datasets. Nonetheless, with a very wide $\mathrm{N}$ and very short $\mathrm{T}$ dimensions (or many cross-sectional 
units and a very short period), using a fixed-effects approach tends to be inappropriate since this procedure consumes an excessive number of degrees of freedom, resulting in inefficient estimation.

\subsection{Research Models}

The current study has a twofold interest: the individual effect of firm innovation types on performance, and the effect of the interaction of process and product innovation and openness on firm performance and CSR.

Drawing on the relevant literature, we selected the following models to test the established hypotheses:

$$
\begin{aligned}
& \text { Performit }=\beta_{0}+\beta_{1} \text { Innovation }_{\text {Type }}+\beta_{2} \text { Innovation Type } \times \text { Open innovation }_{i t}+\text { Control Variables }_{i t}+u_{i t} \\
& \operatorname{CSR}_{i t+1}=\alpha_{0}+\alpha_{1} \text { Innovation Type }_{i t}+\alpha_{2} \text { Innovation Type } \times \text { Open innovation }_{i t}+\text { Control Variables }_{i t}+\varepsilon_{i t}
\end{aligned}
$$

where: perform is measures of firm economic performance: ROA is net income after tax over total assets, and market share is the market share reported by the firm [60]. CSR is an index representing the number of categories of local contribution engaged by the firm. As for CSR activities, GSO data provides information on corporate contributions towards 8 categories: environment, education, infrastructure, health, youth, poverty relief, heritage preservation, and sports. When a firm makes a contribution in any category, it receives 1 point, and 0 otherwise, following [61].

Innovation is analyzed under 2 aspects: Product and Process, in addition to whether it is an open or closed innovation. Product innovation is a dummy variable receiving 1 if significant or minor product improvements are made or new products were introduced in the respective year, and 0 otherwise [20]. Process innovation is a dummy variable receiving 1 if significant or minor process enhancements were introduced or a new process was devised for the production/delivery of products, and 0 otherwise [20]. Open innovation receives 1 if firms innovate with the support of external partners, and 0 if firms only rely on internal R\&D efforts for innovative activities, consistent with [62].

Size is calculated as the natural logarithm of total assets [63]; Leverage is the ratio of total debt to total assets, to control for the possible impact of leverage on a firm's CSR [64]; Competition measures the pressure from market competition, receiving the value of 1 if firms declare that they have competitor(s) and 0 if none, to control for the link between competition and CSR [65]; Export is the ratio of sales from exporting to total sales to control for the effect of export strategy on CSR [66]. For the CSR-related equation, we added the csrcontrol variable, which is a dummy variable receiving 1 if the firm declares that it has a unit to monitor CSR activities, and 0 otherwise. We aim to tackle endogeneity between CSR and innovation (as suggested in [18]) by lagging all explanatory variables in model (2) compared to the period of the explained variable. In model (2), firm profitability is added to control for the ability that a profitable firm may be flexible to invest more in CSR to legitimize its existence [63].

\section{Results and Discussion}

From Table 1, it is clear that firms are interested in engaging in product innovation and process innovation (with the latter being implemented a little less frequently). Accordingly, average ROA is 0.6 percent, which is pretty low. The mktshr variable's average value is 24.236 , or the domestic market share is roughly 24 percent in the region where firms operates, for firms in the sample. The CSR index's value is 1.71 out of 8 , suggesting that, on average, it contributes towards two out of eight areas in the local community. External innovation average value is just 0.204 , much lower than that of product and process counterparts, probably indicating that external collaboration requires intensive resources and is much more involved, which is why firms are much less able to perform this type of innovation. Correlation matrix shows that pairwise correlation is not very high, and performing a Variance Inflation Factor test, whose results are all lower than 10 for the three models above, confirms that multicollinearity is not likely to be a real concern. 
Table 1. Mean and correlation matrix of selected variables.

\begin{tabular}{ccccccccc}
\hline Variable & Obs & Mean & mktshr & ROA & CSR & Process & Product & Open \\
\hline mktshr & 18,237 & 24.236 & 1.000 & & & & & \\
ROA & 22,801 & 0.006 & 0.027 & 1.000 & & & & \\
CSR & 23,379 & 1.710 & 0.048 & 0.026 & 1.000 & & & \\
process & 17,926 & 0.823 & 0.097 & 0.023 & 0.063 & 1.000 & & \\
product & 20,236 & 0.906 & 0.084 & 0.007 & 0.050 & 0.169 & 1.000 & \\
open & 10,698 & 0.204 & 0.165 & 0.050 & 0.163 & 0.209 & 0.157 & 1.000 \\
\hline
\end{tabular}

Source: Authors' calculation from research data.

Table 2 shows the estimation results for the individual impact of process and product innovations and on firm economic performance. Product and process innovations have significantly positive effects on firm performance when proxied by market share, but yield insignificant coefficients in the case of ROA. This result suggests that innovation makes the products/services more appealing in terms of features or price, aiding firms in sustaining market share or even gaining more customers. However, it may take more time before profitability is gained, because innovation is a highly costly activity. This result is in line with hypothesis 1 on the merits of product and process innovations on firm performance.

Process innovation (process) leads to improvements in the methods of production or delivery of products/services, while product innovation (product) delivers improved goods/services in terms of use, characteristics, or components. Upgraded technologies, changing customer tastes and shortening product life cycles are rational drivers of innovations within firms. Theory of creative destruction emphasizes the importance of innovation in creating competitive advantage superior to that of noninnovative counterparts. In other words, product and process innovations can be seen as a sustainable channel to facilitate economic growth and economic performance.

Table 2. Product and process innovations and firm performance.

\begin{tabular}{ccccc}
\hline Variable & mktshr & mktshr & ROA & ROA \\
\hline process & $5.579^{* * * *}$ & & & 0.002 \\
& $(0.555)$ & & & $(0.002)$ \\
product & & $6.889^{* * *}$ & 0.000 & \\
& & $(0.677)$ & $(0.002)$ & \\
size & $0.821^{* * *}$ & $0.828^{* * *}$ & $0.012^{* * *}$ & $0.012^{* * *}$ \\
& $(0.164)$ & $(0.161)$ & $(0.001)$ & $(0.001)$ \\
lev & $-0.007^{* * *}$ & -0.274 & $-0.083^{* * *}$ & $-0.087^{* * *}$ \\
& $(0.001)$ & $(0.226)$ & $(0.005)$ & $(0.005)$ \\
competition & $-3.361^{* * *}$ & $-4.295^{* * *}$ & -0.003 & -0.002 \\
& $(0.837)$ & $(0.844)$ & $(0.002)$ & $(0.002)$ \\
export & $-0.086^{* * *}$ & $-0.086^{* * *}$ & $0.000^{* *}$ & $0.000^{*}$ \\
& $(0.008)$ & $(0.008)$ & 0.000 & 0.000 \\
cons & $13.76^{* * *}$ & $13.825^{* * *}$ & $-0.065^{* * *}$ & $-0.068^{* * *}$ \\
& $(1.797)$ & $(1.842)$ & $(0.007)$ & $(0.007)$ \\
\hline $\mathrm{N}$ & 13923 & 15428 & 18575 & 16472 \\
\hline
\end{tabular}

Source: Author's calculation. ${ }^{*}$ denotes significance at $10 \%$; ${ }^{* * *}$ denotes significance at $1 \%$.

Table 3 provides the results for the estimation of models with interaction between open innovation and process and product innovation on firm performance. The individual coefficients of product and process innovations are no longer significant, while the coefficients of interaction of both these variables and open innovation are significantly positive at $1 \%$ and become much stronger than the individual coefficient, with only one exception in the case of ROA and process innovation. This is clear evidence in support of $\mathrm{H} 2$, emphasizing the role of the collaboration with external partners in conducting innovations. 
Firms need external partners in R\&D activities to develop and maintain competitiveness and the utmost economic success. Open innovation is expected to help firms transcend beyond traditional operating models and lift up firm boundaries. Gobbo and Olsson [43] argue that innovation includes both the search for knowledge novelty and the application of available knowledge, which is essential to materialize firms' potentials. Inauen and Schenker-Wicki [42] suggest that companies focusing on open innovation are more likely to perform radical innovations, and are able to sell a higher quantity of new products.

Radical innovations are inherently more uncertain and complex, thus requiring difficult skills compared to incremental innovation [45]. Radical innovation enables firms to enhance value, rarity, and inimitability, helping firms to maintain the foundation for competitive edge. Rubera and Kirca [44] found that radical innovations are more of an enabler for positive performance, compared to incremental innovations. The role of newness of innovation could be particularly helpful in an environment where minor innovations could easily imitate other firms' innovative efforts. In a developing context, resources for R\&D research, such as capital and human capital, are considerably limited. In this setting, open innovation should play a critical role in spurring firms' radical innovations, which would ultimately lead to higher firm performance.

Table 3. Product and process innovations, open innovation, and firm performance.

\begin{tabular}{ccccc}
\hline Variable & ROA & mktshr & ROA & mktshr \\
\hline \multirow{2}{*}{ product } & -0.001 & -0.033 & & \\
product_open & $(0.003)$ & $(0.707)$ & & \\
& $0.004^{*}$ & $9.999^{* * *}$ & & \\
size & $(0.002)$ & $(0.923)$ & & $0.963^{* * *}$ \\
& $0.013^{* * *}$ & $0.931^{* * *}$ & $0.013^{* * *}$ & $(0.176)$ \\
lev & $(0.001)$ & $(0.177)$ & $(0.001)$ & -0.252 \\
& $-0.084^{* * *}$ & -0.351 & $-0.083^{* * *}$ & $(0.335)$ \\
competition & $(0.005)$ & $(0.359)$ & $(0.005)$ & 1.123 \\
& $-0.005^{*}$ & 0.986 & -0.004 & $(0.854)$ \\
export & $(0.003)$ & $(0.859)$ & $(0.003)$ & $-0.071 * * *$ \\
& 0 & $-0.069 * * *$ & 0 & $(0.008)$ \\
process & 0.000 & $(0.008)$ & 0.000 & -0.387 \\
& & & 0.001 & $(0.594)$ \\
process_open & & & $(0.002)$ & $9.515^{* * *}$ \\
& & & 0.003 & $(0.965)$ \\
_cons & $-0.07^{* * *}$ & $9.203^{* * *}$ & $-0.072 * * *$ & $8.993^{* * *}$ \\
& $(0.008)$ & $(1.974)$ & $(0.008)$ & $(1.900)$ \\
\hline N & 9959 & 9606 & 9814 & 9507 \\
\hline
\end{tabular}

Source: Authors' calculation from research data. ${ }^{*}$ denotes significance at $10 \%$; ${ }^{* * *}$ denotes significance at $1 \%$.

With regard to CSR activities, Tables 4 and 5 indicate that product innovation individually correlates with higher education contribution, while process innovation tends to lead firms to contribute more in environmental and health areas. A potential reason why innovation may lead to higher social contribution is that the contributions may be a signaling channel of firm sustainability to address any concern over any transaction-specific investment [18]. Clearly, if the firm is not sustainable, a stakeholder's specific investment would be wasted in the long term. A firm's CSR can be an effective channel to signal firm sustainability because this activity is highly observable and sufficiently costly [55]. This finding confirms the importance of CSR in reassuring stakeholders about the focal firm's sustainability. As for managerial perspective, stakeholders may lack information to assess SMEs' innovation efficiency in Vietnam; as a result, managers should invest in CSR activities to satisfy different types of stakeholders, gain their trust and support, which altogether enables firms to access more resources and enhances firm performance. 
As for the interaction variable between product, process innovation, and open innovation (Tables 4 and 5), the interaction coefficients are strongly significant in most categories of social contribution. The fact that those interactions are significant in the cases of social contribution again confirms that firms that are more innovative tend to perform corporate social responsibility towards local community. Especially, when firms engage in open innovation, which usually leads to more radical outcomes/achievements, more transaction-specific investment must be involved. In this case, stakeholders are more likely to be concerned about the sustainability of the focal firms. Compared to closed innovations which require less resource, clearly open innovation could bring bigger losses if the firms are not sustainable. This could lead firms to rely on CSR to signal their sustainability.

Table 4. Product innovation, open innovation, and CSR.

\begin{tabular}{|c|c|c|c|c|c|c|c|c|}
\hline Variable & Envi & Edu & Infra & Health & Youth & Povty & Heritage & Sport \\
\hline product & $\begin{array}{c}0.04 \\
(0.03)\end{array}$ & $\begin{array}{l}0.03 * \\
(0.02)\end{array}$ & $\begin{array}{l}-0.02 \\
(0.02)\end{array}$ & $\begin{array}{l}-0.01 \\
(0.01)\end{array}$ & $\begin{array}{c}0.00 \\
(0.01)\end{array}$ & $\begin{array}{c}0.01 \\
(0.03)\end{array}$ & $\begin{array}{l}-0.01 \\
(0.01)\end{array}$ & $\begin{array}{l}-0.02 \\
(0.02)\end{array}$ \\
\hline product_open & $\begin{array}{c}0.117^{* * *} \\
(0.02)\end{array}$ & $\begin{array}{c}0.051^{* * *} \\
(0.01)\end{array}$ & $\begin{array}{c}0.062^{* * *} \\
(0.01)\end{array}$ & $\begin{array}{c}0.044^{* * *} \\
(0.01)\end{array}$ & $\begin{array}{c}-0.052^{* * *} \\
(0.01)\end{array}$ & $\begin{array}{c}0.105^{* * *} \\
(0.02)\end{array}$ & $\begin{array}{l}0.013 \\
(0.01)\end{array}$ & $\begin{array}{l}0.057 \\
(0.01)\end{array}$ \\
\hline size & $\begin{array}{l}0.005 \\
(0.01)\end{array}$ & $\begin{array}{c}0.016^{* * * *} \\
(0.01)\end{array}$ & $\begin{array}{l}0.002 \\
(0.00)\end{array}$ & $\begin{array}{c}0.013^{* * *} \\
(0.00)\end{array}$ & $\begin{array}{c}-0.004 \\
(0.00)\end{array}$ & $\begin{array}{l}0.004 \\
(0.01)\end{array}$ & $\begin{array}{c}0 \\
(0.00)\end{array}$ & $\begin{array}{c}0.02 \\
(0.00)\end{array}$ \\
\hline lev & $\begin{array}{c}-0.029 \\
(0.03)\end{array}$ & $\begin{array}{c}-0.023 \\
(0.02)\end{array}$ & $\begin{array}{l}0.004 \\
(0.02)\end{array}$ & $\begin{array}{c}-0.021 \\
(0.01)\end{array}$ & $\begin{array}{l}0.018 \text { * } \\
(0.01)\end{array}$ & $\begin{array}{c}-0.016 \\
(0.03)\end{array}$ & $\begin{array}{l}0.005 \\
(0.01)\end{array}$ & $\begin{array}{l}0.013 \\
(0.02)\end{array}$ \\
\hline competition & $\begin{array}{c}0.01 \\
(0.02)\end{array}$ & $\begin{array}{l}0.014 \\
(0.02)\end{array}$ & $\begin{array}{l}0.012 \\
(0.01)\end{array}$ & $\begin{array}{l}0.019 \\
(0.01)\end{array}$ & $\begin{array}{c}-0.013 \\
(0.01)\end{array}$ & $\begin{array}{l}0.013 \\
(0.02)\end{array}$ & $\begin{array}{c}0.021 \text { ** } \\
(0.01)\end{array}$ & $\begin{array}{l}0.014 \\
(0.01)\end{array}$ \\
\hline export & $\begin{array}{c}0.00 \\
(0.00)\end{array}$ & $\begin{array}{c}0.00 \\
(0.00)\end{array}$ & $\begin{array}{c}0.00 \\
(0.00)\end{array}$ & $\begin{array}{c}0.00 \\
(0.00)\end{array}$ & $\begin{array}{c}0.00 \\
(0.00)\end{array}$ & $\begin{array}{c}0.00 \\
(0.00)\end{array}$ & $\begin{array}{c}0.00 \\
(0.00)\end{array}$ & $\begin{array}{c}0.00 \\
(0.00)\end{array}$ \\
\hline $\mathrm{ROA}$ & $\begin{array}{l}-0.037 \\
(0.09)\end{array}$ & $\begin{array}{l}0.069 \\
(0.07)\end{array}$ & $\begin{array}{l}0.031 \\
(0.04)\end{array}$ & $\begin{array}{l}0.044 \\
(0.04)\end{array}$ & $\begin{array}{c}-0.036 \\
(0.04)\end{array}$ & $\begin{array}{l}0.043 \\
(0.08)\end{array}$ & $\begin{array}{l}0.046 \\
(0.04)\end{array}$ & $\begin{array}{l}-0.01 \\
(0.05)\end{array}$ \\
\hline _cons & $\begin{array}{c}0.147^{* *} \\
(0.07)\end{array}$ & $\begin{array}{c}-0.1^{* *} \\
(0.05)\end{array}$ & $\begin{array}{l}0.033 \\
(0.04)\end{array}$ & $\begin{array}{c}-0.091 \text { ** } \\
(0.04)\end{array}$ & $\begin{array}{c}1.03^{* * *} \\
(0.03)\end{array}$ & $\begin{array}{c}0.116 \text { * } \\
(0.06)\end{array}$ & $\begin{array}{l}0.034 \\
(0.04)\end{array}$ & $\begin{array}{c}-0.157 \\
(0.05)\end{array}$ \\
\hline $\mathrm{N}$ & 2369 & 2369 & 2369 & 2369 & 2369 & 2369 & 2369 & 2369 \\
\hline
\end{tabular}

Table 5. Process innovation, open innovation, and CSR.

\begin{tabular}{|c|c|c|c|c|c|c|c|c|}
\hline Variable & Environment & Education & Infrastructure & Health & Youth & Poverty & Heritage & Sport \\
\hline \multirow{2}{*}{ process } & $0.06^{* * *}$ & 0.02 & 0.01 & $0.02 * *$ & 0.00 & 0.02 & 0.00 & 0.01 \\
\hline & $(0.02)$ & $(0.02)$ & $(0.01)$ & $(0.01)$ & $(0.01)$ & $(0.02)$ & $(0.01)$ & $(0.01)$ \\
\hline \multirow{2}{*}{ process_open } & $0.11^{* * *}$ & $0.05^{* * *}$ & $0.05^{* * *}$ & $0.05^{* * *}$ & $-0.06^{* * *}$ & $0.10^{* * *}$ & 0.01 & $0.05^{* * *}$ \\
\hline & $(0.02)$ & $(0.02)$ & $(0.01)$ & $(0.01)$ & $(0.01)$ & $(0.02)$ & $(0.01)$ & $(0.01)$ \\
\hline \multirow{2}{*}{ size } & 0.00 & $0.02^{* * *}$ & 0.00 & $0.01^{* * *}$ & 0.00 & 0.01 & 0.00 & $0.02^{* * *}$ \\
\hline & $(0.01)$ & $(0.01)$ & $(0.00)$ & $(0.00)$ & $(0.00)$ & $(0.01)$ & $(0.00)$ & $(0.00)$ \\
\hline \multirow[b]{2}{*}{ lev } & -0.02 & -0.01 & 0.00 & -0.03 * & $0.02 *$ & -0.03 & 0.01 & 0.01 \\
\hline & $(0.04)$ & $(0.02)$ & $(0.02)$ & $(0.02)$ & $(0.01)$ & $(0.03)$ & $(0.01)$ & $(0.02)$ \\
\hline \multirow{2}{*}{ competition } & 0.01 & 0.01 & 0.01 & 0.01 & -0.01 & 0.01 & 0.01 & 0.01 \\
\hline & $(0.02)$ & $(0.02)$ & $(0.01)$ & $(0.01)$ & $(0.01)$ & $(0.02)$ & $(0.01)$ & $(0.02)$ \\
\hline \multirow{2}{*}{ export } & 0.00 & 0.00 & 0.00 & 0.00 & 0.00 & 0.00 & 0.00 & 0.00 \\
\hline & 0.00 & 0.00 & 0.00 & 0.00 & 0.00 & 0.00 & 0.00 & $(0.00)$ \\
\hline \multirow{2}{*}{ ROA } & -0.08 & 0.09 & 0.04 & 0.05 & -0.05 & 0.03 & 0.06 & 0.00 \\
\hline & (0.09) & $(0.07)$ & $(0.04)$ & $(0.05)$ & $(0.04)$ & $(0.08)$ & $(0.04)$ & $(0.06)$ \\
\hline \multirow{2}{*}{ _cons } & $0.16^{* *}$ & -0.08 & 0.01 & $-0.07^{*}$ & $1.03^{* * *}$ & 0.08 & 0.04 & $-0.15^{* * *}$ \\
\hline & $(0.07)$ & $(0.05)$ & $(0.04)$ & $(0.04)$ & $(0.03)$ & $(0.06)$ & $(0.03)$ & $(0.04)$ \\
\hline $\mathrm{N}$ & 2226 & 2226 & 2226 & 2226 & 2226 & 2226 & 2226 & 2226 \\
\hline
\end{tabular}

Source: Authors' calculation from research data. ${ }^{*}$ denotes significance at $10 \%$; ${ }^{*} 5 \%$; ${ }^{* * *} 1 \%$, respectively.

The results are consistent for both process and product innovations across multiple types of CSR activities. However, not all categories of contribution receive equal attention of firms: they are inclined to contribute to environmental preservation, educational campaigns, infrastructure upgrading, social health, poverty alleviation, and some sporting activities. These areas clearly could lead to a more sustainable development of the local community. Nonetheless, heritage preservation and youth 
development may not be the interest of innovative firms. This evidence may suggest that those areas that receive firms' contributions may be more highly observable and more costly to be an effective signaling channel. Compared to other papers that just compute the overall CSR index [61], this paper has practical and theoretical contributions by showing which area may act better than others in terms of signaling, i.e., areas other than heritage preservation and youth improvement programs.

\section{Conclusions}

Manufacturing firms play an important role in Vietnam for their contribution towards employment and income, and are significant drivers for the industrialization and modernization strategy of the whole economy. In the new era, product and process innovations specifically support firms' sustainability since they help firms to maintain a competitive edge in increasingly competitive global and regional markets. However, literature remains limited with regard to the individual and interactive impact of these two innovation types with external collaboration on firm performance in the manufacturing industry. In addition, the impact on innovation on a firm's overall performance as well as other firm strategies, including CSR, is underexplored. This study aims to contribute to the literature with respect to the gaps mentioned.

Our study draws from two datasets from GSO for the period from 2011 to 2013, covering large numbers of firms. Research findings suggest that both process and product innovations have significantly positive impacts on firm performance. To be more specific, this result suggests that innovation makes the products/services more appealing in terms of features or price, aiding firms in sustaining market share or even gaining more customers. However, it may take more time before profitability is gained, because innovation is a highly costly activity.

As mentioned earlier, product and process innovations are statistically significant drivers of firms' market share. However, when the interaction of these innovation types and open innovation is introduced, the product and process innovations are no longer individually significant. This implies that innovations conducted with the support of external partners tend to be more beneficial compared to closed ones. This highlights the merits of open innovation in the context of emerging markets, where SMEs tend to lack resources to conduct innovations. Also, the finding is in line with the argument that radical innovations, which are often the outcome of the collaboration with external partners, tend to earn more desirable performance. Therefore, firms in developing countries should consider partnering with different stakeholders to enhance their innovative capacity and create more successful products.

Our study further confirms that open innovation is a risky process compared to a closed one; as a result, the outcomes of open innovations are highly uncertain. This implies that if firms are not sustainable, a stakeholder's specific investment would be wasted in the long run, leading firms to try to signal their sustainability to gain stakeholders' support. Our findings suggest that highly innovative firms use CSR as a signaling channel, especially when there is externality involved. We also extend the literature by showing that firms do not equally prioritize all categories of local contributions. This may imply that some types of contribution may be more observable and costly than others, which helps the former become more effective as a signaling channel. Specifically, contributions to the areas of environmental protection, education, infrastructure, public health and poverty alleviation tend to be prioritized by firms, since these areas could be highly observable. Meanwhile, youth activities, heritage preservation and sports contribution are less preferred.

Future studies could benefit by incorporating details on the way firms conduct open innovation, i.e., depth, breadth, when interacting with process and product innovations. Also, this study was unable to uncover the long-term impact of innovation on firm performance due to data limitations (only 3 years). It would be of interest to see how depth and breadth of open innovation come into play with firm performance in the long run (3-5 years). Finally, it would help to investigate the link using a more updated dataset, since the current trend of deeper economic integration and technological advancement may have some influence on the link between innovation and firm performance in Vietnam. 
Author Contributions: Conceptualization-N.T.L., N.T.C.; Formal analysis-N.T.L., N.T.C., P.A.T., N.V.K.; Writing—draft: N.T.L., N.T.C., P.A.T., N.V.K.; Writing—review \& editing-N.T.L., N.T.C., P.A.T., N.V.K.

Funding: This research paper was funded by Vietnam National University-Ho Chi Minh City under research project No. B2018-34-01.

Conflicts of Interest: The authors declare no conflict of interest.

\section{References}

1. Schumpeter, J.A. Capitalism, Socialism and Democracy; Routledge: London, UK, 1942; pp. 82-85.

2. OECD. Proposed Guidelines for Collecting and Interpreting Technological Innovation Data; OECD: Paris, France, 1997.

3. Klewitz, J.; Hansen, E.G. Sustainability-oriented innovation of SMEs: A systematic review. J. Clean. Prod. 2014, 65, 57-75. [CrossRef]

4. Hall, B.H. Innovation and Productivity; National Bureau of Economic Research: Cambridge, CA, USA, 2011.

5. Mohnen, P.; Hall, B.H. Innovation and productivity: An update. Eurasian Bus. Rev. 2013, 3, 47-65.

6. Berg, S.V.; Duncan, J.; Friedman, P. Joint Venture Strategies and Corporate Innovation; Oelgeschlager, Gunn \& Hain: Cambridge, MA, USA, 1982.

7. Hagedoorn, J. Understanding the rationale of strategic technology partnering: Nterorganizational modes of cooperation and sectoral differences. Strateg. Manag. J. 1993, 14, 371-385. [CrossRef]

8. Chesbrough, H. The Logic of Open Innovation: Managing Intellectual Property. Calif. Manag. Rev. 2003, 45, 33-58. [CrossRef]

9. Osano, H.M.; Koine, P.W. Role of foreign direct investment on technology transfer and economic growth in Kenya: A case of the energy sector. J. Innov. Entrep. 2016. [CrossRef]

10. Sofka, W.; Grimpe, C. Specialized search and innovation performance-evidence across Europe. RED Manag. 2010, 40, 310-323.

11. Laursen, K.; Salter, A. Open for innovation: The role of openness in explaining innovation performance among UK manufacturing firms. Strateg. Manag. J. 2006, 27, 131-150. [CrossRef]

12. Behringer, K.; Szegedi, K. The Role of CSR In Achieving Sustainable Development-Theoretical Approach. ESJ 2016, 12, 10. [CrossRef]

13. Pizzi, S. The Relationship between Non-Financial Reporting, Environmental Strategies and Financial Performance. Empirical Evidence from Milano Stock Exchange. Adm. Sci. 2018, 8, 76. [CrossRef]

14. Drexhage, J.; Murphy, D. Sustainable Development: From Brundtland to Rio 2012. Background Paper Prepared for Consideration by the High Level Panel on Global Sustainability at Its First Meeting 19 September 2010; United Nations Headquarters: New York, NY, USA, 2010.

15. Steurer, R.; Langer, M.E.; Konrad, A.; Martinuzzi, A. Corporations, Stakeholders and Sustainable Development I: A Theoretical Exploration of Business-Society Relations. J. Bus. Ethics 2005, 61, 263-281. [CrossRef]

16. Watts, P. Corporate Social Responsibility: Making Good Business Sense; World Business Council for Sustainable Development: Geneva, Switzerland, 2000.

17. Ramani, S.V.; Mukherjee, V.J.T. Can breakthrough innovations serve the poor (bop) and create reputational (CSR) value? Indian case studies. Technovation 2014, 34, 295-305. [CrossRef]

18. Shen, R.; Tang, Y.; Zhang, Y. Does Firm Innovation Affect Corporate Social Responsibility? SSRN Electron. J. 2016, 1-37. [CrossRef]

19. Philbeck, T.; Davis, N.; Larsen, A.M.E. Values, Ethics and Innovation: Rethinking Technological Development in the Fourth Industrial Revolution; World Economic Forum: Geneva, Switzerland, 2018.

20. Manual, O. Proposed Guidelines for Collecting and Interpreting Technological Innovation Data; OCDE: Paris, France, 2005.

21. Griffith, R.; Huergo, E.; Mairesse, J.; Peters, B. Innovation and Productivity across Four European Countries. Oxf. Rev. Econ. Policy 2006, 22, 483-498. [CrossRef]

22. Slater, S.F.; Mohr, J.J.; Sengupta, S. Radical product innovation capability: Literature review, synthesis, and illustrative research propositions. J. Prod. Innov. Manag. 2014, 31, 552-566. [CrossRef]

23. Schumpeter, J.A. The Influence of Protective Tariffs on the Industrial Development of the United States. Proc. Acad. Political Sci. 1940, 19, 2-7. [CrossRef] 
24. Hall, B.H.; Lotti, F.; Mairesse, J. Innovation and Productivity in SMEs-Empirical Evidence for Italy. Small Bus. Econ. 2009, 33, 13-33. [CrossRef]

25. Waheed, A. Innovation and Firm-Level Productivity: Econometric Evidence from Bangladesh and Pakistan; UNU-MERIT: Maastricht, The Netherlands, 2011.

26. Tuan, N.; Nhan, N.; Giang, P.; Ngoc, N. The effects of innovation on firm performance of supporting industries in Hanoi, Vietnam. J. Ind. Eng. Manag. 2016, 9, 413. [CrossRef]

27. Rosli, M.M.; Sidek, S. The Impact of Innovation on the Performance of Small and Medium Manufacturing Enterprises: Evidence from Malaysia. J. Innov. Manag. Small Mediu. Enterp. 2013, 2013, 885666. [CrossRef]

28. Tuan, N.P. Gender, innovation and the growth of small medium enterprises: An empirical analysis of Vietnam's manufacturing firms. VNU J. Sci. Econ. Bus. 2012, 28, 87-102.

29. Fagerberg, J.; Mowery, D.C.; Nelson, R.R. The Oxford Handbook of Innovations; Oxford University Press: Oxford, UK, 2004.

30. Foster, L.; Haltiwanger, J.; Syverson, C. Reallocation, Firm Turnover, and Efficiency: Selection on Productivity or Profitability? Am. Econ. Rev. 2008, 98, 394-425. [CrossRef]

31. Mairesse, J.; Robin, S. Innovation and Productivity: A Firm-Level Analysis for French Manufacturing and Services Using CIS3 and CIS4 Data (1998-2000 and 2002-2004); CREST-ENSAE: Paris, France, 2009.

32. Cassiman, B.; Golovko, E.; Martinez-Ros, E. Innovation, exports and productivity. Int. J. Ind. Organ. 2010, 28, 372-376. [CrossRef]

33. Parida, V.; Westerberg, M.; Frishammar, J. Inbound Open Innovation Activities in High-Tech SMEs: The Impact on Innovation Performance. J. Small Bus. Manag. 2012, 50, 283-309. [CrossRef]

34. Cheng, C.C.J.; Huizingh, E.K.R.E. When Is Open Innovation Beneficial? The Role of Strategic Orientation. J. Prod. Innov. Manag. 2014, 31, 1235-1253. [CrossRef]

35. Greco, M.; Grimaldi, M.; Cricelli, L. An analysis of the open innovation effect on firm performance. Eur. Manag. J. 2016, 34, 501-516. [CrossRef]

36. Duysters, G.; Lokshin, B. Determinants of Alliance Portfolio Complexity and Its Effect on Innovative Performance of Companies. J. Prod. Innov. Manag. 2011, 28, 570-585. [CrossRef]

37. Koput, K.W. A Chaotic Model of Innovative Search: Some Answers, Many Questions. Organ. Sci. 1997, 8, 528-542. [CrossRef]

38. Lin, J.-Y. Effects on diversity of R \& D sources and human capital on industrial performance. Technol. Forecast. Soc. Chang. 2014, 85, 168-184.

39. Kang, K.H.; Kang, J. How do firms source external knowledge for innovation? Analysing effects of different knowledge sourcing methods. Int. J. Innov. Manag. 2009, 13, 1-17. [CrossRef]

40. Bayona-Sáez, C.; García-Marco, T.; Sanchez-García, M.; Cruz-Càzares, C. The impact of open innovation on innovation performance: The case of Spanish agri-food firms. In Open Innovation in the Food and Beverage Industry; Elsevier: Amsterdam, The Netherlands, 2013; pp. 74-94.

41. Gobbo, J.A., Jr.; Olsson, A.J.T. The transformation between exploration and exploitation applied to inventors of packaging innovations. Technovation 2010, 30,322-331. [CrossRef]

42. Inauen, M.; Schenker-Wicki, A.; Armano, B.; Scagnelli, S.D.; Schenker-Wicki, A. Fostering radical innovations with open innovation. Eur. J. Innov. Manag. 2012, 15, 212-231. [CrossRef]

43. Leifer, R.; McDermott, C.M.; O'Connor, G.C.; Peters, L.S.; Mark, R.P.; Rice, M.; Veryzer, R.W. Radical Innovation: How Mature Companies can Outsmart Upstarts; Harvard Business Press: Brighton, MA, USA, 2000.

44. Rubera, G.; Kirca, A.H. Firm Innovativeness and Its Performance Outcomes: A Meta-Analytic Review and Theoretical Integration. J. Mark. 2012, 76, 130-147. [CrossRef]

45. Flammer, C. Does product market competition foster corporate social responsibility? Evidence from trade liberalization. Strateg. Manag. J. 2015, 36, 1469-1485. [CrossRef]

46. Mattingly, J.E.; Berman, S.L. Measurement of corporate social action: Discovering taxonomy in the Kinder Lydenburg Domini ratings data. Bus. Soc. 2006, 45, 20-46. [CrossRef]

47. Caputo, F.; Veltri, S.; Venturelli, A. A Conceptual Model of Forces Driving the Introduction of a Sustainability Report in SMEs: Evidence from a Case Study. Int. Bus. Res. 2017, 10, 39. [CrossRef]

48. Kim, Y.; Brodhag, C.; Mebratu, D. Corporate social responsibility driven innovation. Innov. Eur. J. Soc. Sci. Res. 2014, 27, 175-196. [CrossRef]

49. Bocquet, R.; Le Bas, C.; Mothe, C.; Poussing, N. Are firms with different CSR profiles equally innovative? Empirical analysis with survey data. Eur. Manag. J. 2013, 31, 642-654. [CrossRef] 
50. Gonzalez-Ramos, M.I.; Donate, M.J.; Guadamillas, F. Technological posture and corporate social responsibility: Effects on innovation performance. Environ. Eng. Manag. J. 2014, 13, 2497-2505. [CrossRef]

51. Zhou, G.; Zhang, L.; Zhang, L. Corporate Social Responsibility, the Atmospheric Environment, and Technological Innovation Investment. Sustainability 2019, 11, 481. [CrossRef]

52. Miller, D.J.; Fern, M.J.; Cardinal, L.B. The Use of Knowledge for Technological Innovation within Diversified Firms. Acad. Manag. J. 2007, 50, 307-325. [CrossRef]

53. Helfat, C.E. Firm-Specificity in Corporate Applied R\&D. Organ. Sci. 1994, 5, 173-184.

54. Hart, O.; Moore, J. Incomplete Contracts and Renegotiation. Econometric 1988, 56, 755. [CrossRef]

55. Spence, A.M. Market Signaling: Informational Transfer in Hiring and Related Screening Processes; Harvard University Press: Cambridge, MA, USA, 1974; Volume 143.

56. Stiglitz, J.E. Equilibrium wage distributions. Econ. J. 1985, 95, 595-618. [CrossRef]

57. Godfrey, P.C.; Merrill, C.B.; Hansen, J.M. The relationship between corporate social responsibility and shareholder value: An empirical test of the risk management hypothesis. Strateg. Manag. J. 2009, 30, 425-445. [CrossRef]

58. Godfrey, P.C. The Relationship between Corporate Philanthropy and Shareholder Wealth: A Risk Management Perspective. Acad. Manag. Rev. 2005, 30, 777-798. [CrossRef]

59. Asongu, S.A.; Nwachukwu, J.C.; Tchamyou, V.S. Information asymmetry and financial development dynamics in Africa. Rev. Dev. Financ. 2016, 6, 126-138. [CrossRef]

60. Gunday, G.; Ulusoy, G.; Kiliç, K.; Alpkan, L. Effects of innovation types on firm performance. Int. J. Prod. Econ. 2011, 133, 662-676. [CrossRef]

61. Newman, C.; Rand, J.; Tarp, F.; Trifkovic, N. The transmission of socially responsible behaviour through international trade. Eur. Econ. Rev. 2018, 101, 250-267. [CrossRef]

62. Zhang, S.; Yang, D.; Qiu, S.; Bao, X.; Li, J. Open innovation and firm performance: Evidence from the Chinese mechanical manufacturing industry. J. Eng. Technol. Manag. 2018, 48, 76-86. [CrossRef]

63. Dyduch, J.; Krasodomska, J. Determinants of Corporate Social Responsibility Disclosure: An Empirical Study of Polish Listed Companies. Sustainability 2017, 9, 1934. [CrossRef]

64. Brammer, S.; Brooks, C.; Pavelin, S. Corporate Social Performance and Stock Returns: UK Evidence from Disaggregate Measures. Financ. Manag. 2006, 35, 97-116. [CrossRef]

65. Quairel-Lanoizelée, F.J.S.; Review, B. Are competition and corporate social responsibility compatible? The myth of sustainable competitive advantage. Soc. Bus. Rev. 2011, 6, 77-98. [CrossRef]

66. Barin Cruz, L.; Boehe, D.M.; Ogasavara, M.H. CSR-based differentiation strategy of export firms from developing countries: An exploratory study of the strategy tripod. Bus. Soc. 2015, 54, 723-762. [CrossRef] 